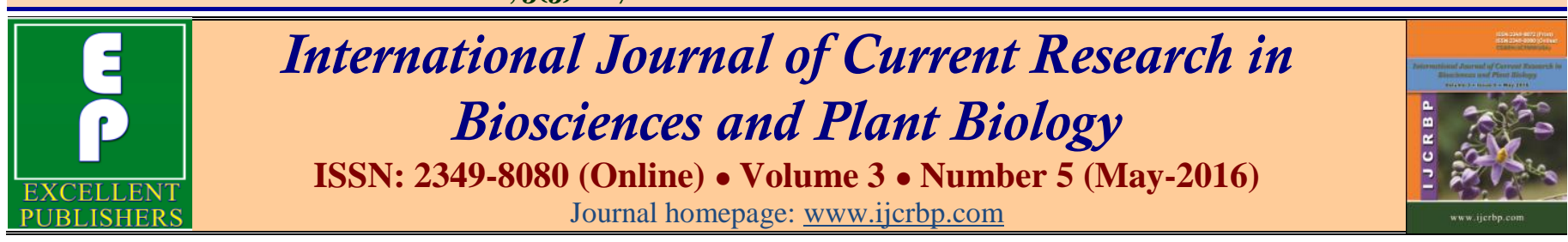

\title{
Application of Different Growth Media for Production of Quality Planting Stock in Salix alba Linn.
}

\author{
Vijay $^{1}$, Rajiv Umrao ${ }^{1}$, Hemant Kumar ${ }^{1}$ and Arvind Bijalwan ${ }^{2}$ \\ ${ }^{1}$ School of Forestry and Environment, Sam Higginbottom Institute of Agriculture, Allahabad-2110o7, Uttar Pradesh, India \\ 'Indian Institute of Forest Management, Bhopal-462 oo3, Madhya Pradesh, India \\ *Corresponding author.
}

\begin{abstract}
A b stract
The present experiment was conducted to study the application of different growth media for production of quality planting stock in Salix alba. Linn. during the spring season in the year 2014-15 at Research Farm of School of Forestry and Environment, SHIATS, Allahabad, Uttar Pradesh, India. The experiment was laid out in randomized block design (RBD) with seven treatments each replicate by three times including control $\mathrm{T}_{0^{-}}$soil, $\mathrm{T}_{1}-$ soil: $\mathrm{FYM}$ : sand (1:1:1), $\mathrm{T}_{2}-$ soil: $\mathrm{FYM}$ : neem cake (1:1:1), $\mathrm{T}_{3}$ soil: FYM: vermicompost (1:1:1), $\mathrm{T}_{4}$ - neem cake: sand: vermicompost $(1: 1: 1), \mathrm{T}_{5}$ - neem cake: soil: vermicompost (1:1:1) and $\mathrm{T}_{6}$ - neem cake: FYM: vermicompost (1:1:1). Four Salix alba clone have taken which were PN-731, PN-224, GPB (Selection) and NZ1002 in the experiment. In view of present experiment the most effective media combination was $\mathrm{T}_{1}$ (soil: sand: FYM 1:1:1) which shows better results in sprouts, survival percentage, number of root, root length and biomass compared to control or other treatments and therefore, it can be recommended that the combination of soil: sand: FYM (1:1:1) as effective treatment for the growth of Salix alba clones.
\end{abstract}

\section{Article Info}

Accepted: 28 March 2016

Available Online: 06 May 2016

\section{Keywords}

Clones

Farm yard manure (FYM)

Neem cake

Salix alba

Survival percentages

\section{Introduction}

Salix alba commonly known as willow is eco-friendly, multipurpose, fast growing and widely used tree species for plantation throughout the world. The genus Salix comprises of about 350 - 500 species worldwide (Argus, 1997), some of which have been cultivated for a variety of uses viz., cricket bats, baskets, furniture, plywood, pulp and paper, rope making, etc. (Verwijst, 2001). Due to its wide geographic adaptation and fast growth, it has a significant economic value. The genus is distributed over wide ecological and climatic zones ranging from North America to China, excluding Australasia (Trybush et al., 2008). The arborescent willow species are able to grow on various types of soil, even compacted, swampy, acidic or alkaline, provided the roots have sufficient moisture.
In India, there are about 31 indigenous and 4 exotic species of willows (Saini and Sharma, 2001), but majority of them are not suitable for industrial use or high bio-mass production except Salix tetrasperma, and $S$. acmophylla which meet limited requirements of industrial uses. One of the most important characters required by entrepreneurs is bole straightness followed by clear bole height and diameter. About 800 bat manufacturing factories have come up in Kashmir valley, Jallandhar, Delhi, Meerut of India covering an annual turnover of Rs. 500 crores and generating employment for 15,000 peoples engaged in sawing, shaping and finishing the blades around 10 million bats are produced every year in India (Anonymous, 2009). Therefore one should give utmost importance for bole straightness of Salix species along with volume production. Arborescent 
species of willow like Salix alba, S. humboltiana, $S$. excelsa, S. acmophyla, S. daphnoides, S. fragilis, $S$. nigra, S. matsudana, S. amygdaloides, S. jessoensis and $S$. tetrasperma and their inter and intra specific hybrids/clones are able to grow by vegetative propagation on a large variety of edaphic, ecological and hydrological conditions and are better adapted in monoculture as well as in agroforestry systems under short rotation forestry. Most of the arborescent species of Salix are confined to hilly region of the country except $S$. tetrasperma which is occurring right from tropical to temperate regions of India.

Vegetative propagation by cuttings has received a lot of attention in recent years in the woody perennials. It is most simple, easiest and widely used tool for establishment of clonal plantations. The nursery plants are raised from cuttings taken from one year old nursery growth. The ability of cuttings to root and their subsequent growth in nursery is determined by number of factors viz. time at which cuttings are taken, age of the donor tree, position within the crown where cuttings are taken, treatment and status of rooting/ biomass conditions under which cuttings are rooted (Puri, 1993) or the seedling quality is characterized by various parameters which are influenced largely by nursery cultural techniques. In tropical and sub-tropical regions the focus is on polybags. The objectives of the present experiment deals with sprouting, survival percentage, number of roots, root length $(\mathrm{cm})$ and total biomass $(\mathrm{g})$ through selected PN-731, PN-224, GPB (Selection) and NZ1002 of Salix alba clones.

\section{Materials and methods}

Experiment was conducted to the study application of different media for the production of quality planting stock in Salix alba in the year 2014-15 during spring season at research farm of School of Forestry and Environment, SHIATS, Allahabad, U P., India. The soil of experimental field was sandy loam having medium to poor drainage, low in available nitrogen, medium in available phosphorus and fairly rich in potassium with $7.5 \mathrm{pH}$. With seven treatment each replicate by three times including control $\mathrm{T}_{0^{-}}$soil; $\mathrm{T}_{1-}$ soil: FYM: sand(1:1:1); $\mathrm{T}_{2}-$ soil: $\mathrm{FYM}$ : neem cake (1:1:1); $\mathrm{T}_{3}$ - soil: FYM: vermicompost (1:1:1); $\mathrm{T}_{4^{-}}$ neem cake: sand: vermicompost $(1: 1: 1) ; \mathrm{T}_{5^{-}}$neem cake: soil: vermicompost (1:1:1); $\mathrm{T}_{6^{-}}$neem cake: FYM: vermicompost $(1: 1: 1)$. Four clone have been taken from Chandra Shekhar Azad University of Agriculture and Technology, Kanpur which are PN-
731, PN-224, GPB (Selection) and NZ1002. The experiment was laid out in Randomized Block Design. The data were recorded and statically analysed of two way variance (ANOVA). Observed parameters are sprouting, survival percentage, number of roots, root length and total biomass.

\section{Results and discussion}

\section{Effect of different media on Salix alba clones}

Sprouting: The result shows in Table 1 and Fig. 1 was analyzed statistically to evaluate the significance of variation due to different clone and treatments. All the treatments were found statistically significantly increased sprouts over control. Most effective treatment was $\mathrm{T}_{1}$ (Soil: Sand: FYM,1:1:1) which had maximum (3.06) sprouts, followed by $\mathrm{T}_{6}$ (vermicompost: FYM:neemcake,1:1:1) with (2.95) sprouts, $\mathrm{T}_{3}$ (soil: sand: vermicompost, 1:1:1) with (2.84) sprouts, $\mathrm{T}_{2}$ (soil : sand : neemcake, 1:1:1) with (2.73)sprouts, $\mathrm{T}_{4}$ (vermicompost : sand : neemcake, 1:1:1) with (2.40) sprouts, $\mathrm{T}_{5}$ (vermicompost: soil: neemcake, 1:1:1) with (2.40). The minimum (2.28) sprouts were recorded in $\mathrm{T}_{0}$ control condition without any treatment of media. Similar results recorded by Haidari (2013) showed that the most effective treatment was mixture of soil: sand: FYM in sprouts, survival percentage under the experiment on performance of poplar cuttings with different growth regulators and potting media.

Survival percentages: The result shows in Table 2 and Fig. 2 was analyzed statistically to evaluate the significance of variation due to different clone and treatments. All the treatments were found statistically significant increased survival percentage over control. Statistically most effective treatment was $\mathrm{T}_{1}$ (Soil: Sand: FYM, 1:1:1) which had maximum (66.00) survival percentage, followed by $\mathrm{T}_{0}$ (control) with (56.00) survival percentage, $\mathrm{T}_{3}$ (Soil: Sand: Vermicompost 1:1:1) with (36.00) survival percentage , $\mathrm{T}_{6}$ (Vermicompost : FYM : Neem cake) with (26.00) survival percentage, $\mathrm{T}_{4}$ (Vermicompost: Sand: Neemcake,1:1:1) with (22.67) survival percentage, $\mathrm{T}_{5}$ (Vermicompost: soil: Neem cake, 1:1:1) with (19.00). The minimum (16.00) survival percentage were recorded in $\mathrm{T}_{2}$ (Soil: sand: Neem cake, 1:1:1) without any treatment of media. Similar trend was noticed at the entire clone. Among the clone most effective clone was GPB (Selection), followed by PN-731, while the minimum recorded in NZ-1002. 
Table 1. Effect of different media on sprouts of Salix alba clones.

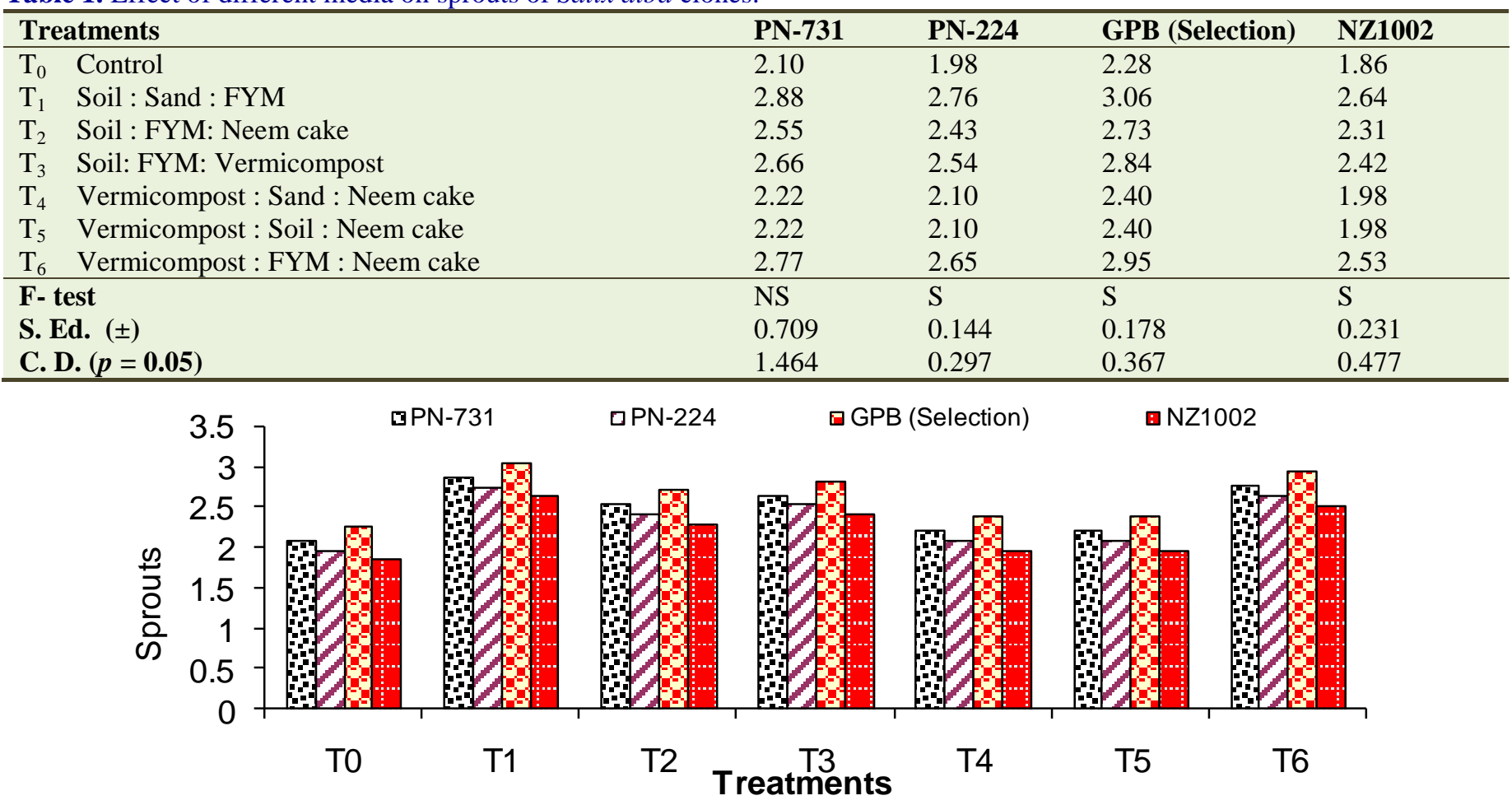

Fig. 1: Effect of different media on sprouts of Salix alba clones.

Table 2. Effect of different media on survival percentage of Salix alba clones.

\begin{tabular}{lllll}
\hline Treatments & PN-731 & PN-224 & GPB (Selection) & NZ1002 \\
\hline $\mathrm{T}_{0}$ Control & 54.33 & 54.66 & 56.00 & 53.66 \\
$\mathrm{~T}_{1} \quad$ Soil : Sand : FYM & 64.33 & 64.66 & 66.00 & 63.66 \\
$\mathrm{~T}_{2}$ Soil : FYM: Neem cake & 14.33 & 14.66 & 16.00 & 13.66 \\
$\mathrm{~T}_{3} \quad$ Soil: FYM: Vermicompost & 34.33 & 34.66 & 36.00 & 33.66 \\
$\mathrm{~T}_{4} \quad$ Vermicompost : Sand : Neem cake & 21.00 & 21.33 & 22.67 & 20.33 \\
$\mathrm{~T}_{5} \quad$ Vermicompost : Soil : Neem cake & 17.67 & 18.00 & 19.00 & 17.00 \\
$\mathrm{~T}_{6} \quad$ Vermicompost : FYM : Neem cake & 24.33 & 24.66 & 26.00 & 23.66 \\
\hline F- test & $\mathrm{NS}$ & $\mathrm{S}$ & $\mathrm{S}$ & $\mathrm{S}$ \\
S. Ed. $( \pm)$ & 0.709 & 0.183 & 0.212 & 0.113 \\
C. D. $(\boldsymbol{p}=\mathbf{0 . 0 5})$ & 1.464 & 0.377 & 0.438 \\
\hline
\end{tabular}

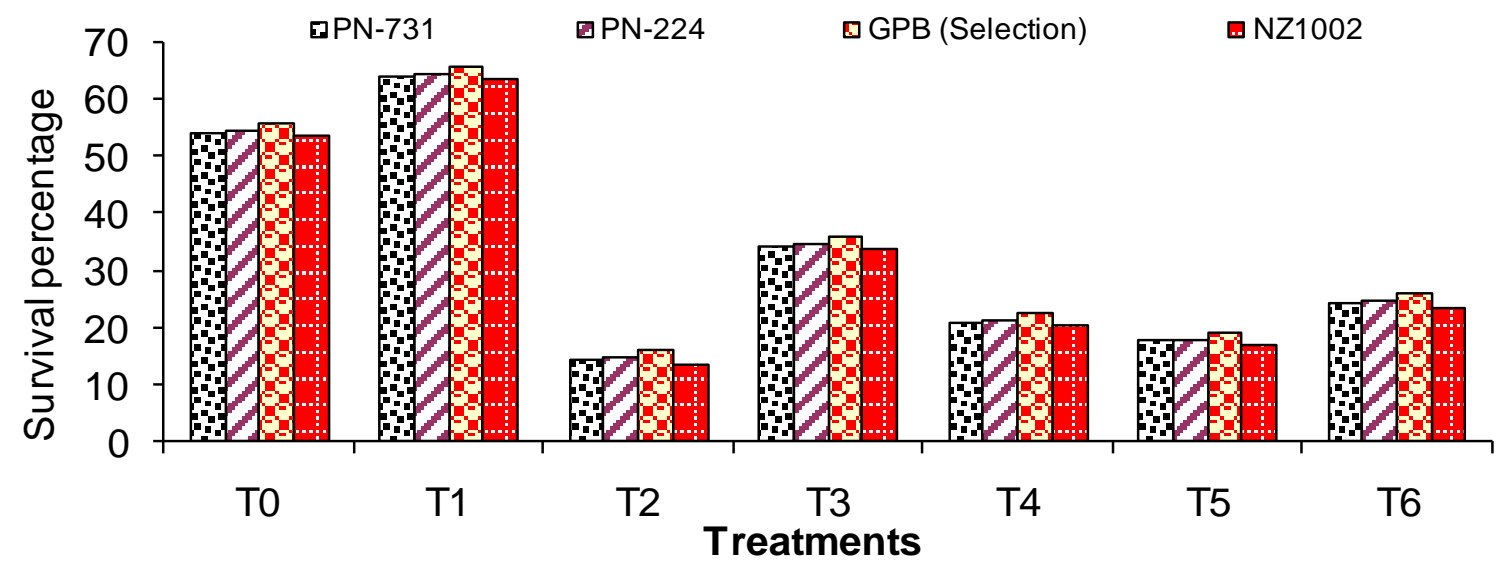

Fig. 2: Effect of different media on survival percentage of Salix alba clones. 
Number of roots: The result shows in Table 3 and Fig. 3 was analyzed statistically to evaluate the significance of variation due to different clone and treatments. All the treatments were found statistically significantly increased number of root over control. Most effective treatment was $\mathrm{T}_{1}$ (Soil: Sand: FYM, $1: 1: 1)$ which had maximum (18.24) number of root, followed by $\mathrm{T}_{5}$ (Vermicompost: soil: Neemcake, 1:1:1) with (16.34) number of root, $\mathrm{T}_{2}$ (Soil: sand: Neemcake,1:1:1) with (15.40) number of root $\mathrm{T}_{4}$ (Vermicompost: Sand: Neemcake,1:1:1) with (12.90) plant shoot length, $\mathrm{T}_{3}$ (Soil: FYM: Vermicompost) with
(11.81) number of root. The minimum (9.50) number of root was recorded in $\mathrm{T}_{0}$ control without any treatment of media. Similar trend was noticed at the entire clone. Among the clone most effective was GPB (Selection), followed by PN-731, while the minimum recorded in NZ-1002. However, Majeed et al. (2009) recorded the highest rooting rate $(50 \%)$ for Aesculus indica cuttings treated with IBA at 2000pp and similar result was found by Mesen et al. (1997). They worked on the effects of different concentrations of IBA, rooting media and cutting origins on the rooting of leafy stem cuttings of Cordia alliodora.

Table 3. Effect of different media on number of root of Salix alba clones.

\begin{tabular}{lllll}
\hline Treatments & PN-731 & PN-224 & GPB (Selection) & NZ1002 \\
\hline $\mathrm{T}_{0}$ Control & 7.83 & 8.16 & 9.50 & 7.16 \\
$\mathrm{~T}_{1} \quad$ Soil : Sand : FYM & 16.57 & 16.90 & 18.24 & 15.90 \\
$\mathrm{~T}_{2}$ Soil : FYM: Neem cake & 13.73 & 14.06 & 15.40 & 13.06 \\
$\mathrm{~T}_{3}$ Soil: FYM: Vermicompost & 10.14 & 10.47 & 11.81 & 9.47 \\
$\mathrm{~T}_{4}$ Vermicompost : Sand : Neem cake & 11.23 & 11.56 & 12.90 & 10.56 \\
$\mathrm{~T}_{5}$ Vermicompost : Soil : Neem cake & 14.67 & 15.00 & 16.34 & 14.00 \\
$\mathrm{~T}_{6}$ Vermicompost : FYM : Neem cake & 8.83 & 9.16 & 10.50 & 8.16 \\
\hline F- test & $\mathrm{S}$ & $\mathrm{S}$ & $\mathrm{S}$ & $\mathrm{S}$ \\
S. Ed. $( \pm)$ & 0.048 & 0.618 & 0.562 & 0.490 \\
C. $\boldsymbol{D} . \boldsymbol{p}=\mathbf{0 . 0 5})$ & 0.099 & 1.275 & 1.159 & 1.011 \\
\hline
\end{tabular}

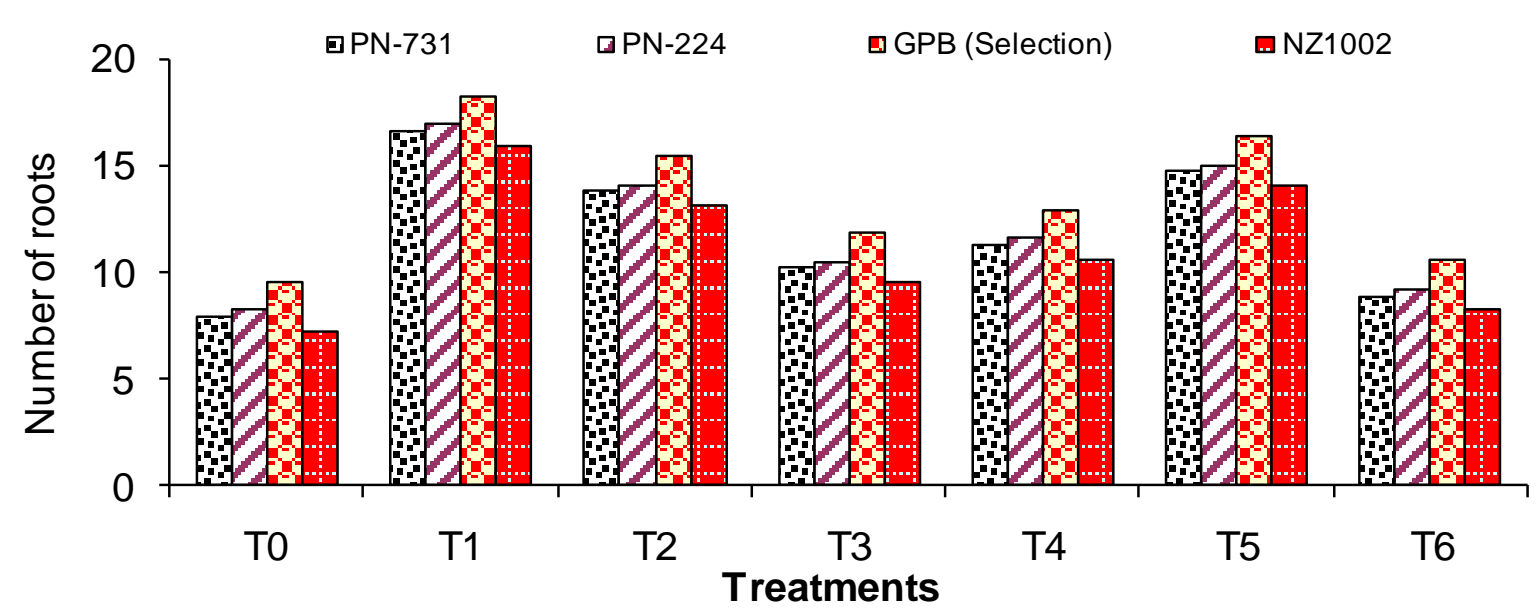

Fig. 3: Effect of different media on number of root of Salix alba clones.

Root length (cm): The result depicted in Table 4 and Fig. 4 was analyzed statistically to evaluate the significance of variation due to different clone and treatments. All the treatments were found statistically significantly increased root length $(\mathrm{cm})$ over control. Most effective treatment was $\mathrm{T}_{6}$ (vermicompost : FYM : neem cake) which had maximum (24.67) root length, followed by $\mathrm{T}_{3}$ (vermicompost: soil: neem cake, 1:1:1) with (16.34) number of root, $\mathrm{T}_{2}$ (Soil: sand: Neemcake, 1:1:1) with (15.40) root length $\mathrm{T}_{4}$ (vermicompost: sand: neemcake,1:1:1) with (12.90) root length, $\mathrm{T}_{3}$ (Soil: FYM: vermicompost) with (24.11) root length. The minimum (19.39) root length were recorded in $\mathrm{T}_{0}$ control without any treatment of media. Similar trend was noticed at the entire clone. Among the clone most effective clone was GPB (Selection), followed by PN731, while the minimum recorded in NZ-1002. A root length range of $16.72-22.00 \mathrm{~cm}$ under different potting media treatment of poplar cutting was recorded by Haidari (2013). 
Table 4. Effect of different media on root length (cm) of Salix alba clones.

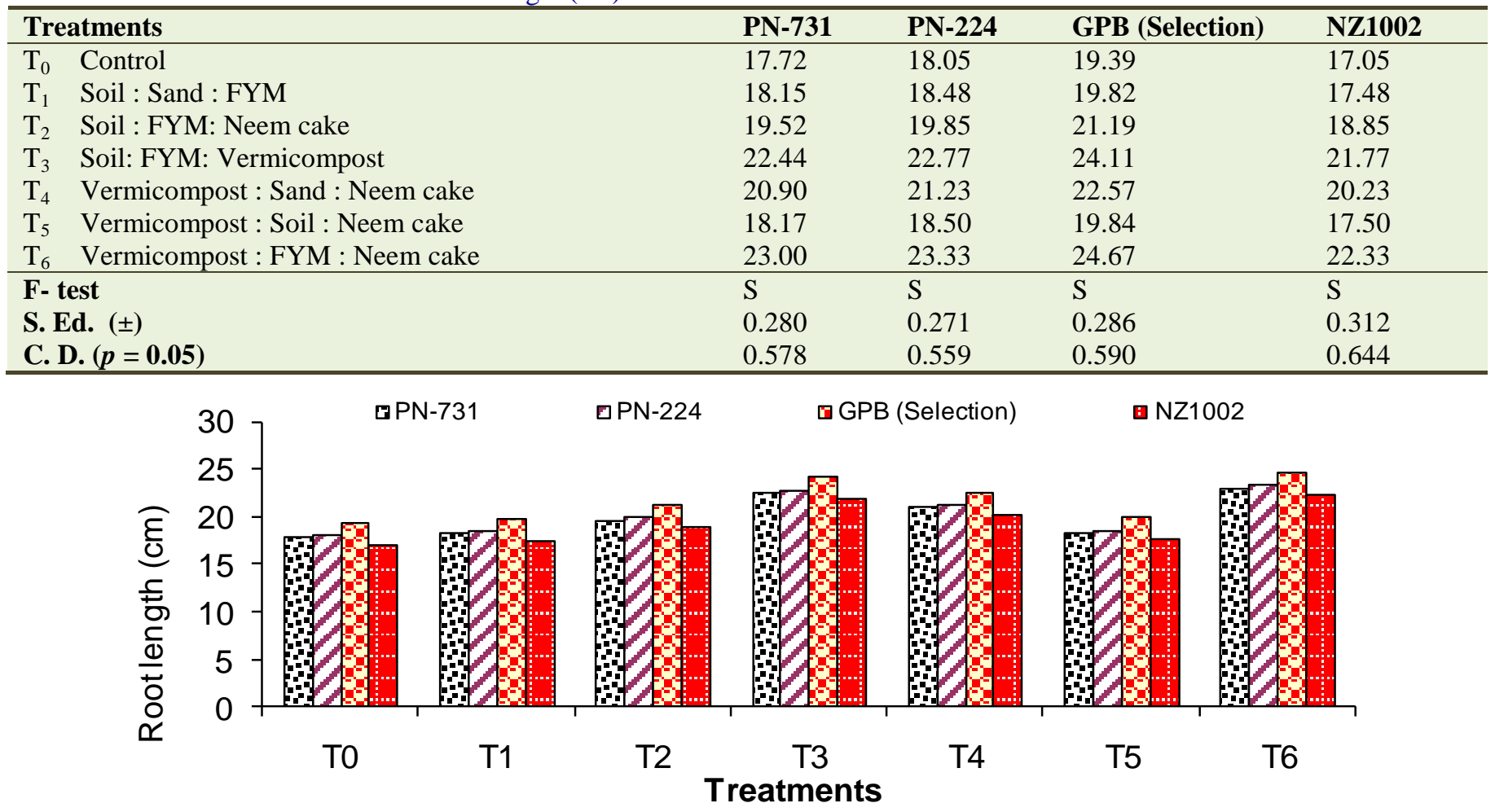

Fig. 4: Effect of different media on root length of Salix alba clones.

Table 5. Effect of different media on total biomass (g) of Salix alba clones.

\begin{tabular}{lllll}
\hline Treatments & PN-731 & PN-224 & GPB (Selection) & NZ1002 \\
\hline $\mathrm{T}_{0}$ Control & 10.49 & 11.15 & 13.83 & 9.15 \\
$\mathrm{~T}_{1}$ Soil : Sand : FYM & 11.74 & 12.40 & 15.17 & 10.40 \\
$\mathrm{~T}_{2}$ Soil : FYM: Neem cake & 11.58 & 12.24 & 14.31 & 10.24 \\
$\mathrm{~T}_{3}$ Soil: FYM: Vermicompost & 10.97 & 11.63 & 14.30 & 9.62 \\
$\mathrm{~T}_{4}$ Vermicompost : Sand : Neem cake & 11.64 & 12.30 & 15.50 & 10.30 \\
$\mathrm{~T}_{5}$ Vermicompost : Soil : Neem cake & 11.67 & 12.33 & 15.07 & 10.33 \\
$\mathrm{~T}_{6}$ Vermicompost : FYM : Neem cake & 12.85 & 13.51 & 16.19 & 11.51 \\
\hline F- test & $\mathrm{S}$ & $\mathrm{S}$ & $\mathrm{S}$ & $\mathrm{S}$ \\
S. :d. $( \pm)$ & 0.060 & 0.052 & 0.080 & 0.351 \\
C. $\boldsymbol{D} . \boldsymbol{p}=\mathbf{0 . 0 5})$ & 0.123 & 0.107 & 0.164 & 0.724 \\
\hline
\end{tabular}

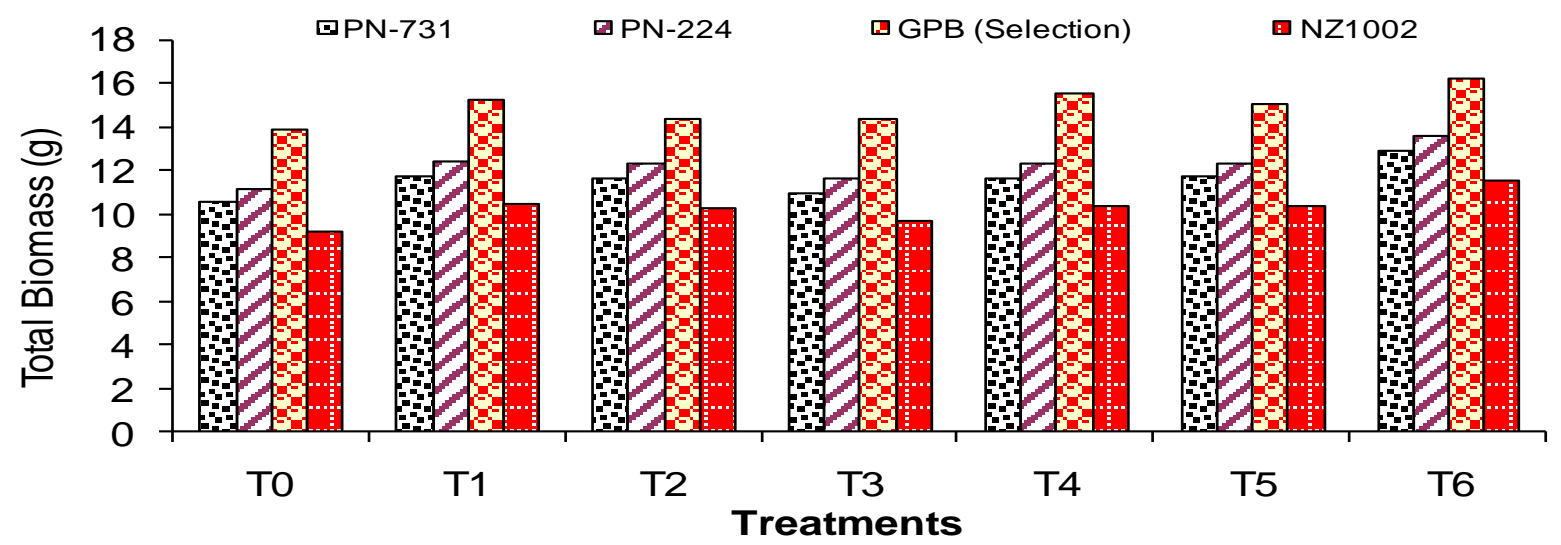

Fig. 5: Effect of different media on total biomass (g) of Salix alba clones. 
Total biomass (g): The result recorded in Table 5 and Fig. 5 was and analyzed statistically to evaluate the significance of variation due to different clone and treatments. All the treatments were found statistically significantly increased total biomass over control. Most effective treatment was $\mathrm{T}_{6}$ (vermicompost : FYM : neem cake) which had maximum (16.19) total biomass, followed by $\mathrm{T}_{4}$ (vermicompost : Sand : Neem cake) with (15.50) total biomass , $\mathrm{T}_{1}$ (soil : sand : FYM) with (15.17) total biomass $T_{5}$ (vermicompost : soil : neem cake) with (15.01) total biomass, $\mathrm{T}_{2}$ (soil: sand: neemcake,1:1:1) with (14.31) total biomass. The minimum (13.83) total biomass was recorded in $\mathrm{T}_{0}$ control $\mathrm{p}$ without any treatment of media. Similar trend was noticed at the entire clone. Among the clone most effective clone was GPB (Selection), followed by PN731, while the minimum recorded in NZ-1002. Similar result was reported by Haidari (2013) while applying vermicompost in poplar cuttings.

\section{Conclusion}

In the view of present experiment the most effective media treatment combination was observed as $\mathrm{T}_{1}$ (Soil: Sand: FYM 1:1:1) and hence recommended for the mass multiplication of Salix alba, however, among the different clones of Salix alba, GPB (selection) was found to be most effective clone.

\section{Conflict of interest statement}

Authors declare that they have no conflict of interest.

\section{References}

Anonymous, 2009. Jammu and Kashmir ban on willow movement boosts smuggling. Economic Times, $14^{\text {th }}$ November.

Argus, G.W., 1997. Infra generic classification of Salix (Salicaceae) in the New World. Systematic Botany Monographs. Vol. 52. The American Society of Plant Taxonomists, USA.

Haidari, A., 2013. Performance of popar cuttings with different growth regulators and potting media. M. Sc. (Forestry) thesis, School of Forestry and Environment, SHIATS, Allahabad.

Majeed, M., Khan, M.A., Mughal, A.H., 2009. Vegetative propagation of Aesulus indica through stem cuttings treated with plant growth regulators. J. For. Res. 20(2), 171-173.

Mesen, J.F., Newton, A.C., Leakey, R.R.B., 1997. Vegetative propagation of Cordia alliodora (Ruiz \& Pavon) Oken: The effect of IBA concentration, propagation medium and cutting origin. Forest Ecol. Manage. 92, 45-54.

Puri, S., 1993. Effect of auxin (IBA and NAA) and season on rooting of juvenile and mature hardwood cuttings of Robina pseudoacacia and Grewia optiva. New For. 23, 142-157.

Saini, B. C., Sharma, P.S., 2001. Salix- A multipurpose tree for future agroforestry. ENVIS Forestry Bull. 1(1), 18-20.

Trybush, S.S, Jahodova, W., Macalpine, A., Karp. (2008): A genetic study of a Salix germplasm resource reveals new insights into relationships among subgenera, sections and species. Bioenergy Res. 1, 67-79.

Verwijst, T., 2001. Willows: An underestimated resource for environment and society. Forestry Chron. 77(2), 251-285.

\section{How to cite this article:}

Vijay, Umrao, R., Kumar, H., Bijalwan, A., 2016. Application of different growth media for production of quality planting stock in Salix alba Linn. Int. J. Curr. Res. Biosci. Plant Biol. 3(5), 107-112. doi: http://dx.doi.org/10.20546/ijcrbp.2016.305.017 